\title{
Deep-fat frying of meat products in palm olein
}

\author{
Fritura por imersão de produtos cárneos em oleína de palma
}

\author{
Cibele Cristina OSAWA ${ }^{1}$, Lireny Aparecida Guaraldo GONÇALVES ${ }^{1 \star}$
}

\begin{abstract}
This study investigated the discontinuous frying of breaded meat products in palm olein in a $28 \mathrm{~L}$-electric fryer maintained at $182{ }^{\circ} \mathrm{C}$ for 8 hours a day. Three 400-500 g batches of meat products were fried for 4.5 minutes daily. For comparison purpose, thermoxidation tests were performed using inert material with added moisture and without the addition of $\mathrm{f}$ ood (heating only). The total polar compound content did not reach the $25 \%$ limit, and nor did the formation of polymerized products exceed $5 \%$, which indicates the good frying performance of palm olein for frying. Other analytical parameters and rapid tests were also evaluated. The sensory attributes, such as odor, colour, and foam formation determined when the frying oils should be discarded. The addition of water to the inert material contributed to the final value of $1.00 \pm 0.01 \%$ (in palmitic acid), while the oil subjected only to heating reached respectively $0.26 \pm 0.02 \%$, and the oils used to fry breaded meat and breaded chicken reached $0.38 \pm 0.00 \%$ and $2.35 \pm 0.01 \%$, respectively. This suggests a protective effect of the water during frying since the oil subjected only to heating was more prone to degradation.
\end{abstract}

Keywords: palm olein; deep-fat frying; meat products.

\section{Resumo}

Este artigo estudou a fritura descontínua de alimentos cárneos empanados em oleína de palma em uma fritadeira elétrica de $28 \mathrm{~L}$, mantida a $182{ }^{\circ} \mathrm{C}$ durante 8 horas por dia. Diariamente, três bateladas de 400-500 g de alimentos cárneos foram fritos durante 4,5 minutos. Para comparação, foram conduzidos testes de termoxidação com a adição de material inerte com umidade adicionada e sem a adição de alimentos (apenas aquecimento). O teor de compostos polares totais não atingiu o limite de $25 \%$ e a formação de compostos polimerizados também não ultrapassou 5\%, refletindo a boa performance da oleína de palma para frituras. Outros parâmetros analíticos, assim como testes rápidos, foram avaliados. Os atributos sensoriais, tais como odor, cor e formação de fumaça, determinaram quando o óleo de fritura deveria ser descartado. A adição de água ao material inerte contribuiu para um valor final de 1,00 \pm 0,01\% (em ácido palmítico), enquanto que o óleo submetido apenas a aquecimento atingiu $0,26 \pm 0,02 \%$ e os óleos usados na fritura de carne empanada e frango empanado, $0,38 \pm 0,00 \%$ e 2,35 $\pm 0,01 \%$, respectivamente. Isso sugere um efeito protetor da água durante a fritura, pois o óleo submetido apenas a aquecimento foi mais susceptível à degradação.

Palavras-chave: oleína de palma; fritura por imersão; alimentos cárneos.

\section{Introduction}

Malaysia is the main producer of palm oil, which is consumed in more than 150 countries (LAI, 2005). In Malaysia, palm oil is the main oil for culinary purposes (BASIRON, 2005) due to the high productivity of the palm tree. Approximately 6 tons of oil can be produced from each hectare of palm trees per year (CALLIAUW; GIBON; GREYT, 2007).

Being a mixture of triacylglycerols with a wide range of melting points, palm oil may be separated by fractionation into liquid and solid fractions, known respectively as olein and stearin (LAI, 2005). Saturated fatty acids are preferentially distributed in the palm stearin. Thus, crude palm olein contains diacylglycerols, squalene, carotenoids, tocopherols, and tocotrienols, while palm stearin contains monoacylglycerols, sterols, and phospholipids (GEE, 2007).

The fractionation of oils and fats is considered a simple, inexpensive, and environmentally friendly technology based on the complex process of crystallization, which to this day is only partially understood. The oil submitted to fractionation is subjected to cooling and controlled crystallization, followed by selective separation by filtration (LAI, 2005; CALLIAUW; GIBON; GREYT, 2007). Palm olein yield is approximately $85 \%$ of the initial palm oil (CALLIAUW; GIBON; GREYT, 2007).

Palm olein, the stearin, and intermediary fractions of the palm are excellent raw materials for formulas and food applications free of trans isomers (GEE, 2007; BERGER, 2005). Stearin is a valuable source of natural fat with a high melting point allowing a large range of applications for the manufacturer of lipid foods, such as margarines and shortenings (LAI, 2005). Like palm oil, palm olein is widely used in industrial frying. It offers a large number of advantages, does not emit undesirable odors, is highly-resistant to oxidation, does not contain linolenic acid, and has a favourable nutritional composition

Received 29/2/2012

Accepted 3/8/2012 (005613)

${ }^{1}$ Laboratory of Oils and Fats, Department of Food Technology, Faculty of Food Engineering, University of Campinas - UNICAMP, CP 6091, CEP 13081-970, Campinas, SP,

Brazil,e-mail: lireny@fea.unicamp.br

${ }^{*}$ Corresponding author 
for being free of trans fatty acids and presenting tocopherols in its composition. It facilitates the production of fried foods of acceptable quality without the need of hydrogenated oils (BASIRON, 2005; MAN et al., 1999).

Deep fat frying is an important method of cooking food, due to its practicality, rapid preparation, and the desirable flavor and texture characteristic of fried foods (LAWSON, 1994). However, during frying, a series of simultaneous reactions occur in the presence of atmospheric air, food, water, and high temperatures such as $180^{\circ} \mathrm{C}$, for example: thermoxidation, polymerization and hydrolysis (STEVENSON; VAISEY-GENSER; ESKIN, 1984).

According to international recommendation, frying oil should be discarded when the acidity exceeds $2.5 \%$, the polar compound content exceeds $25 \%$, the frying temperature is higher than $180^{\circ} \mathrm{C}$, and the frying oil is not organoleptically acceptable (PAUL; MITTAL, 1997).

A vast amount of studies carried out on fried potatoes can be found in the literature, but studies addressing meat produce are rare. Fried breaded meat products are very well-accepted by consumers and are frequently found in food services. Additionally, the role of the water and the temperature on frying oils, in comparison with the food frying, has not yet been studied.

This study had the following objectives: a) to evaluate the degradation of the palm olein used in the discontinuous frying of breaded meat products using physicochemical methods and rapid tests; b) to compare the degradation of the palm olein used in the frying of breaded chicken with the degradation of the palm olein during the frying of an inert material (hydrolysis and thermoxidation) and with the degradation occurring during the heating of the oil (thermoxidation); and, c) to evaluate changes in food after frying with respect to moisture content, oil incorporation, fatty acid composition, and formation of trans isomers.

\section{Material and methods}

\subsection{Frying protocol}

The fryer used in the frying procedure was FryMaster ${ }^{\circ}$ electric fryer (donated by McDonald's, Brazil) with 2 tanks, each with dimensions of $34.5 \mathrm{~cm} \times 51.0 \mathrm{~cm}$. Only one tank was used adding $28 \mathrm{~L}$ of oil. The initial ratio between the surface of the fryer and the volume of oil (S/V) was $0.06 \mathrm{~cm}^{-1}$. During the frying cycles, there was no replenishment with fresh oil to replace that absorbed by the foods, and the oil was not filtered.

One frying cycle of frozen breaded skinless and deboned chicken breast (Braslo, Brazil) was carried out in refined and deodorised palm olein (Agropalma, Brazil); one frying cycle of frozen breaded beef meat (Braslo, Brazil) in palm olein; one frying cycle of inert material (sponges made of polyurethane and synthetic fiber with abrasive, measuring $110 \times 75 \times 20 \mathrm{~mm}$ from $3 \mathrm{M}$, Brazil) in palm olein; and 1 heating cycle of palm olein carried out at $182{ }^{\circ} \mathrm{C}$ without food. For the same frying cycle, only one type of food was used (breaded meat or breaded chicken), the inert material, or the olein, was subjected only to heating at $182^{\circ} \mathrm{C}$. The foods had not been previously fried and were kept frozen until frying.

The daily frying protocol followed the following stages:

- First, the fryer was turned on, and the oil was heated for 3 hours at $182^{\circ} \mathrm{C}$ before adding food/inert material to fry; the first frying was then carried out. After another 3 hours at $182^{\circ} \mathrm{C}$, the second frying of the day was carried out. Finally, after a further 2 hours at $182{ }^{\circ} \mathrm{C}$, the last frying was carried out, and the fryer was turned off until the next day. The fryer was turned on for 8 hours daily, with the oil at $182^{\circ} \mathrm{C}$, and the lid was left open during the natural cooling process of the oil;

- For each batch, the frying time was 4.5 minutes at a temperature of $182^{\circ} \mathrm{C}$;

- Each frying batch varied according to the food being fried: approximately $400 \mathrm{~g}$ of breaded chicken or $500 \mathrm{~g}$ of breaded meat or 3 sponges, each cut into 4 rectangular pieces, with the addition of a total of $120 \mathrm{~g}$ of distilled water. The amount of water added to the inert material represented $30 \%$ of moisture present in the foods.

The frying cycles were carried out under the same experimental conditions, using the same kind of foods and the same frying oil. The quantities of fried breaded meat products and the duration of each frying cycle are shown in Table 1.

The end of each cycle and the discarding of the frying oil were determined by the rapid tests and by the sensory characteristics of the frying oil and fried foods. This occurred after 17 days of breaded chicken frying and 7 days of breaded meat frying. In the case of frying the inert material (also fried

Table 1. Amount of breaded meat products (g) used in frying and amount of water added to the fried inert material.

\begin{tabular}{cccc}
\hline Time (Days) & Chicken & Meat & Hydrated inert material $^{\mathrm{a}}$ \\
\hline 0 & 1204.2 & 1319.7 & 121.2 \\
1 & 1212.3 & 1697.3 & 120.5 \\
2 & 1226.6 & 1664.8 & 121.0 \\
3 & 1199.8 & 1705.4 & 120.8 \\
4 & 1220.5 & 1688.9 & 121.0 \\
5 & 839.5 & 1676.8 & 121.3 \\
6 & 1222.3 & 1568.3 & 122.6 \\
7 & 1229.5 & $\mathrm{~b}$ & 123.2 \\
8 & 1212.1 & - & 123.2 \\
9 & 1224.6 & - & 126.2 \\
10 & 1227.5 & - & 124.0 \\
11 & 1207.7 & - & 122.7 \\
12 & 1214.2 & - & 123.1 \\
13 & 1248.3 & - & 122.3 \\
14 & 1262.3 & - & 123.7 \\
15 & 1233.8 & - & 124.1 \\
16 & 1187.9 & - & 122.0 \\
17 & $\mathrm{~b}$ & - & $\mathrm{b}$ \\
\hline
\end{tabular}

a'Referring to the amount of water added to the inert material (g); ${ }^{\mathrm{b}}$ Oil submitted only to heating. 
for 4.5 minutes) or heating the oil without adding food, the time of duration of the experiments was established according to the longest time of frying, namely, after 17 days of oil usage, in order to compare them with those used in the frying cycles of the breaded products. The physicochemical changes were determined using the same determinations used for the oils for frying meat products.

After the frying stages, approximately $200 \mathrm{~g}$ of each fried food was tasted by untrained judges in order to detect undesirable odours and flavours. The remaining fried foods were wrapped in polyethylene films and stored frozen for subsequent determinations. The samples were thawed and subsequently shredded using a food processor for the analyses.

Changes in the frying oil were measured daily before starting the frying procedures using the rapid tests Testo 265 (Testo do Brasil, Brazil), Viscofrit (Laboratorio de Seguridad Alimentaria, Spain), and Fri-Check (Frais Imp. E Exp. Ltda, Brazil); and $100 \mathrm{~mL}$ samples were collected for further analyses. The samples were transferred to amber flasks and stored frozen until analysis.

\subsection{Determinations in foods}

Moisture: determined according to AOAC official method 950.46B (HORWITZ, 1980) using $10 \mathrm{~g}$ of shredded sample.

Oil content: determined by acid hydrolysis according to the procedures adopted by Osawa (2005). Due to the nature of protein foods with or without significant carbohydrate contents, acid hydrolysis is required to free the the lipids covalently bonded to the proteins and carbohydrates (SHAHIDI; WANASUNDARA, 1998).

\subsection{Frying oils analyses}

Lovibond Color: determined according to AOCS official method Cc 13e-92 (AMERICAN..., 2004), using a Lovibond Tintometer model E with $51 / 4$ ", 1" or 0.5 " glass cuvettes, in quadruplicate.

Free Fatty Acids: determined according to the method described by Osawa, Gonçalves and Ragazzi (2006), in duplicate, using a $1.5 \mathrm{~g}$ sample for fresh oils and $1.0 \mathrm{~g}$ sample for used oils and the TitroLine easy titrator (SCHOTT, Germany) instead of the indicator phenolphthalein, which is subject to human error. The titrator was adjusted for an end-point of $\mathrm{pH}=8.8$.

Conjugated Dienes: determined according to AOCS official method Ti 1a-64 (AMERICAN..., 2004) in duplicate.

Polar Compounds and Polymeric Compounds: determined in duplicate according to the method developed by Dobarganes, Velasco and Dieffenbacher (2000) using open column chromatography. One g of the filtered sample was dissolved in $10 \mathrm{~mL}$ of petroleum ether: diethyl ether 90:10 (v/v) (solution 1). An open glass chromatographic column (10 mm internal diameter, $150 \mathrm{~mm}$ length, polytetrafluorethylene tube with glass joints) was prepared by adding $5 \mathrm{~g}$ of previously activated silica gel, particle size 0.063-0.200 mm (Merck nº 7734 or equivalent), activated at $160{ }^{\circ} \mathrm{C}$ for at least 4 hours, and adjusted to $5 \%$ moisture content. The dissolved sample was applied to the top of the column. The non-polar fraction was eluted with $60 \mathrm{~mL}$ of solution 1 at a flow rate of approximately $1.5 \mathrm{~mL} / \mathrm{min}$ into in a100 $\mathrm{mL}$ round-bottomed flask with ground glass neck. The polar fraction was then eluted with ethyl ether into another $100 \mathrm{~mL}$ round-bottomed flask with ground glass neck. The solvents used to extract the polar and non-polar fractions were evaporated off using a rotary evaporator. The apolar and polar fractions were then quantified by weight difference.

The effectiveness of the chromatographic separation was confirmed using thin-layer chromatography, applying $2 \mu \mathrm{L}$ of the non-polar matter solutions $(10 \%$ in petroleum ether or ethyl ether) to a thin-layer chromatographic plate $(20 \times 20 \mathrm{~cm} \times$ $0.25 \mathrm{~mm}$ ) with a $0.25 \mathrm{~mm}$ thick silica gel layer, using a capillary pipette (specific for thin-layer chromatography), in comparison with a standard sample of refined oil with both polar and nonpolar fraction. The mobile phase used was petroleum ether: diethyl ether: acetic acid (70:40:1), and visualization was carried out using sublimed iodine at about $40{ }^{\circ} \mathrm{C}$.

The polar fraction was dissolved in tetrahydrofuran at a concentration of $0.01 \mathrm{~g} . \mathrm{mL}^{-1}$ for quantification of the polymeric compounds. The polymeric compounds were separated using a Perkin Elmer liquid phase chromatograph equipped with a Waters 510 pump and Rheodyne 7725i injector with a $20 \mu \mathrm{L}$ sampler (Waters Associates, USA). Two gel permeation columns, one of 500 and the other $100 \hat{A}$, connected in series and filled with cross-bound styrene divinylbenzene copolymer particles were used. Each column was $25 \mathrm{~cm}$ in length with an internal diameter of $0.77 \mathrm{~cm}$. The mobile phase was chromatographic grade tetrahydrofuran at a flow rate of $1.0 \mathrm{~mL} / \mathrm{minute}$. A Merck L-7490 refractive index detector (Merck, Germany) was used together with a Hewlett-Packard HP 3390A integrator (HewlettPackard, USA).

Fatty Acid composition: The esterification method according to the Hartman and Lago (1973) was used. The methyl esters obtained were injected into an Agilent Gas Chromatograph series 8850 GC System, using an Agilent DB23 capillary column (50\% cyanopropyl - methylpolysiloxane) measuring $60 \mathrm{~m}$ in length with an internal diameter of $0.25 \mathrm{~mm}$ and $0.25 \mu \mathrm{m}$ stationary phase. The temperatures employed were: detector at $280^{\circ} \mathrm{C}$, injector at $250{ }^{\circ} \mathrm{C}$, oven at $195^{\circ} \mathrm{C}$ for 20 minutes, $195-215^{\circ} \mathrm{C}\left(5^{\circ} \mathrm{C} / \mathrm{min}\right)$, and $215^{\circ} \mathrm{C}$ for 16 minutes. Helium was used as the stripper gas at a flow rate of $1.00 \mathrm{~mL} / \mathrm{min}$ using a split ratio of 1:50 and linear speed of $24 \mathrm{~cm} / \mathrm{second}$. A volume of $1.0 \mu \mathrm{L}$ was injected using an automatic injector.

Oxidative Stability: determined according to AOCS official method Cd 12b-92 (AMERICAN..., 2004), in duplicate, using the Oxidative Stability Instrument (OSI) (Omnion Archer - Daniels Midland Company), a sample of $5 \mathrm{~g}$, temperature of $130^{\circ} \mathrm{C}$, and air flow of $9.2 \mathrm{~L} /$ hour.

Tocopherol and Tocotrienol Contents: determined according to AOCS official method Ce 8-89 (AMERICAN..., 2004) using $\alpha, \beta, \gamma$ and $\delta$-tocopherol standards (Calbiochem, $95 \%$ of purity) and preparing 7 stock solutions of approximately 1.4 and $18.0 \mu \mathrm{g} . \mathrm{mL}^{-1}$ to construct calibration curves. A Perkin 
Elmer 250 liquid phase chromatograph with an isocratic pump coupled to a Shimadzu RF-10 AXL detector (excitation-290 nm; emission-330 nm) was used. A Merck Li Chrosorb Si 60 column $(250 \times 4 \mathrm{~mm})$ coupled to a compatible standby column was used. The mobile phase was a mixture of hexane and isopropanol (99:1), both HPLC grade, and the flow rate was $1.1 \mathrm{~mL} /$ minute.

Rapid Tests: Three rapid tests were used, namely Viscofrit, Fri-Check ${ }^{\circledast}$ and Testo 265 according to the manufacturer's instructions. Viscofrit evaluates whether a sample can be continued used in frying operations, i.e, whether the total polar compound content has surpassed $25 \%$ and therefore should be discarded. Fri-Check and Testo 265 express results in terms of percentage of total polar compounds present in the samples.

\section{Results and discussion}

\subsection{Total polar compounds and rapid tests}

The total polar compounds did not reach the limit of $25 \%$ in the frying cycle of chicken in palm olein up to 17 days of frying (Table 2). However, the experiment was stopped at this point since the oil was condemned sensorially and was emitting a great amount of smoke.

The same behaviour was observed for the frying of breaded meat, which only lasted 7 days. Sensory alterations were observed, which affected the odour of the oil and the taste of the food, accompanied by the presence of smoke and foaming. The low level of total polar compounds could possibly be due to the presence of spices with antioxidant properties in the product.

The shorter time of use of the oil used to fry the breaded meat samples could be attributed to the visibly larger amount of flour (or bread crumbs) from the breaded meat floating in the oil than that of the flour from the breaded chicken (not quantified) during frying. According to Warner (2004), the accumulation of flour residue in the fryer deteriorates the oil faster.

Table 2. Experimental results of total polar compounds of the palm olein samples used in frying the meat products and inert material and that submitted only to heating using rapid tests and the conventional open column method.

\begin{tabular}{lccccc}
\hline Sample & $\begin{array}{c}\text { Days of } \\
\text { frying }\end{array}$ & $\begin{array}{c}\text { Official } \\
\text { method }^{\mathrm{a}}\end{array}$ & Testo 265 & Fri-check & $\begin{array}{c}\text { Viscofrit: } \\
\text { TPC }>25 \% ?^{\text {? }}\end{array}$ \\
\hline Breaded & 0 (Fresh) & $7.0 \pm 0.0$ & $10.3 \pm 1.0$ & $3.9 \pm 1.2$ & - \\
chicken & 11 & $14.4 \pm 0.8$ & $11.7 \pm 0.3$ & $4.6 \pm 0.1$ & No \\
& 17 & $22.9 \pm 0.2$ & $16.7 \pm 0.8$ & $5.6 \pm 0.1$ & No \\
Breaded & 0 (Fresh) & $8.2 \pm 1.9$ & $12.2 \pm 0.3$ & $14.9 \pm 1.2$ & - \\
meat & 7 & $11.9 \pm 1.1$ & $13.3 \pm 0.6$ & $4.5 \pm 0.6$ & No \\
Inert & 0 (Fresh) & $7.0 \pm 0.0$ & $11.0 \pm 0.5$ & $3.4 \pm 0.3$ & - \\
material & 11 & - & $19.3 \pm 0.6$ & $5.2 \pm 0.5$ & No \\
& 17 & $17.8 \pm 0.5$ & $23.2 \pm 0.8$ & $5.4 \pm 0.8$ & No \\
Heating & 0 (Fresh) & $7.0 \pm 0.0$ & $11.0 \pm 0.5$ & $3.0 \pm 0.1$ & - \\
only & 11 & - & $\underline{24.7 \pm 0.3}$ & $12.8 \pm 1.3$ & $\underline{\text { YES }}$ \\
& 17 & $\underline{27.8 \pm 1.6}$ & $\underline{28.7 \pm 0.6}$ & $17.9 \pm 1.1$ & $\underline{\text { YES }}$ \\
\hline
\end{tabular}

${ }^{a}$ Results for total polar compounds (TPC) in $\%$; ${ }^{\text {tTPC }}>25 \%$ ? = is the TPC content higher than $25 \%$ ?; YES = Yes, the TPC content is higher than $25 \%$ and the oil should be discarded; No $=$ No, the TPC content is smaller than $25 \%$ and the oil may be continuously used.
When discarded, the frying oils used to fry the inert material and the breaded chicken, and that subjected only to heating, showed total polar compound contents of $17.8 \pm 0.5 \%$; $22.9 \pm 0.2 \%$ and $27.8 \pm 1.6 \%$, respectively. Thus, the palm olein subjected only to heating presented a greater amount of total polar compounds than the palm olein used in the frying of breaded chicken, and the latter showed more total polar compounds than the frying oil used to fry the inert material.

The effects of temperature and oxygen contributed to a greater degree to the degradation of the oil than the effect of the temperature and oxygen combined with the effect of water, or the effect of the latter combined with food residues. The food residues present in the oil may catalyze degradation of the oil (PAUL; MITTAL, 1997), and the spices present in the breaded chicken may have an antioxidant effect (BELITZ; GROSCH, 1999).

With respect to the frying of inert material, according to the values determined for the total polar compounds, it can be said that the effect of the water was less damaging to the quality of the oil as expressed by the formation of total polar compounds than the interactions of the food with the oil being heated or than the effect of temperature and atmospheric oxygen. This is due to the protective effect of the water evaporated, which generates a vaporizing and distilling effect. Due to vaporization and distillation, there is a decrease in the dissolved oxygen concentration and the expulsion of oxidized volatile compounds and probably of free radicals formed during the frying process (DANA; BLUMENTHAL; SAGUY, 2003).

Comparing the results of the rapid tests with those of the determination of total polar compounds by the conventional method, nothing can be said about the accuracy of these tests, given the small number of samples containing total polar compounds close to the limit of 25\% (Table 2). In the present study, these tests were used for a rapid quantification and prediction of the total polar compound content in order to determine the end of the experiments for the frying cycles since the conventional method takes a long time to produce such results.

Nevertheless, the results supplied by the Testo 265 were closer to those of the conventional method for the quantification of total polar compounds based on adsorption liquid chromatography using a silica gel column. The Fri-check showed non-uniform behavior, tending to underestimate the results. The Viscofrit, on the other hand, proved to be a reliable and accurate tool corroborating information found in the literature with low rates of false positives and false negatives, $4.8 \%$ and $1.9 \%$, respectively (MARMESAT et al., 2007).

\subsection{Polar compounds and their fractions}

The generation of polymerized products in palm olein was minimal for both breaded chicken and breaded meat, while the oil, when subjected only to heating, was more prone to the formation of oxidized triacylglycerols than that used in the frying of inert material (Table 3). The same can be said about the formation of oxidized triacylglycerols (TG oxidized) and diacylglycerols (DG). 
Table 3. Evaluation of total polar compounds (TPC) and oxidized compounds in the oil used for frying and the oil only submitted to heating.

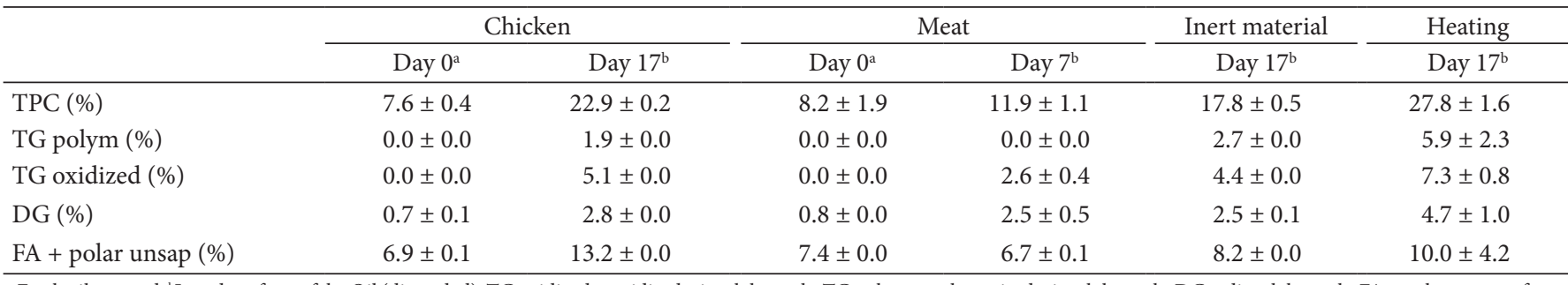

${ }^{a}$ Fresh oil, unused; ${ }^{b}$ Last day of use of the Oil (discarded); TG oxidized $=$ oxidised triacylglycerols; TG polym = polymerised triacylglycerols; DG $=$ diacylglycerols; FA + polar unsap = fatty acid + unsaponifiable polar material.

The formation of oxidized triacylglycerols and diacylglycerols prevailed in the oil used for frying breaded chicken, while in the oils used for frying breaded meat and inert material and in the oil subjected only to heating, the formation of fatty acids (FA) + unsaponifiable polar material and oxidized triacylglycerols prevailed (Table 3 ).

Comparing the composition of the polar material formed in the oils used for frying foods with that of the compounds formed in the oil subjected only to heating, it can be said that the addition of the food did not cause any increase in the degree of polymerization of the oil, as reported by Kalogianni, Karastogiannidou and Karapantsios (2009), who fried potatoes in palm oil. To the contrary, in the case of frying breaded meat, the degree of polymerization was even lower.

The effect of water on the polar composition of frying oils has not been studied before. From the results shown in Table 3 , one can say that the protective effect of the water, resulting in the expulsion of oxidized volatile compounds and free radicals formed during frying (DANA; BLUMENTHAL; SAGUY, 2003), leads to a lower degree of polymerization reactions during frying, resulting in low levels of oxidized triacylglycerols, polymerized triacylglycerols and dimerized triacylglycerols.

\subsection{Free fatty acids}

With respect to the free fatty acid content, the addition of water to the inert material contributed to the final value of $1.00 \pm 0.01 \%$ (as palmitic acid), while the fatty acid content of the oil subjected only to heating was only $0.26 \pm 0.02 \%$ (as palmitic acid) (Table 4). This result was expected, since the water present in the inert material interacted with the palm olein causing hydrolytic reactions, which resulted in larger amounts of free fatty acids such as diacylglycerol, monoacylglycerol, and glycerol (PAUL; MITTAL, 1997).

In the case of the breaded meat, which presented relatively low levels of total polar compounds and free fatty acids, $11.9 \pm 1.1 \%$ polar compounds and $0.38 \pm 0.00 \%$ (palmitic acid), respectively, the spices present in the food may have inhibited lipid oxidation, and hence the degree of hydrolysis after 7 days of frying was relatively low.

With respect to frying breaded chicken in palm olein, the discarded oil had $2.35 \pm 0.01 \%$ (palmitic acid) of fatty acids. Although different kind of food was fried, the fact that the oil used to fry the breaded chicken was used for a longer period
Table 4. \% FFA in the palm olein samples used for frying the breaded meat products and inert material and in that only submitted to heating.

\begin{tabular}{|c|c|c|}
\hline \multicolumn{2}{|c|}{ Sample } & \multirow{2}{*}{$\frac{\% \mathrm{FFA}^{\mathrm{a}}}{0.06 \pm 0.00}$} \\
\hline Chicken & Day $0^{\text {b }}$ & \\
\hline & Day 11 & $0.90 \pm 0.01$ \\
\hline & Day $17^{\mathrm{c}}$ & $2.35 \pm 0.01$ \\
\hline \multirow[t]{2}{*}{ Meat } & Day $0^{\mathrm{b}}$ & $0.05 \pm 0.00$ \\
\hline & Day $7^{c}$ & $0.38 \pm 0.00$ \\
\hline \multirow[t]{3}{*}{ Inert material } & Day $0^{\mathrm{b}}$ & $0.02 \pm 0.00$ \\
\hline & Day 11 & $0.4 \pm 0.01$ \\
\hline & Day $17^{\mathrm{c}}$ & $1.00 \pm 0.01$ \\
\hline \multirow[t]{3}{*}{ Heating only } & Day $0^{\mathrm{b}}$ & $0.02 \pm 0.00$ \\
\hline & Day 11 & $0.18 \pm 0.01$ \\
\hline & Day $17^{c}$ & $0.26 \pm 0.02$ \\
\hline
\end{tabular}

a\% as Palmitic acid; ${ }^{\mathrm{b}}$ Fresh Oil, unused; 'Last Day of use of the Oil (Discarded).

(17 days) and its higher amount of moisture than the meat samples (approximately $65 \%$ and $57 \%$, respectively) could explain its greater amount of free fatty acids since it was exposed to a greater amount of water during the frying cycle.

\subsection{Oxidative stability}

The induction period for fresh oils at $130{ }^{\circ} \mathrm{C}$ was approximately 12 hours (Table 5 ). For the frying cycles studied, however, this period was reduced to $4.8 \pm 0.1$ hours for the breaded chicken cycle and $6.4 \pm 0.0$ hours for the breaded meat cycle. These results agree with the results obtained for total polar compounds, which were lower for the breaded meat sample.

In addition, the oil subjected only to heating was the one with the highest content of total polar compounds (Tables 2 and 3), and consequently it showed the shortest induction period, $0.3 \pm 0.1$ hours, followed by the inert material sample submitted to hydrolysis (Table 5).

\subsection{Conjugated dienes and color}

The conjugation of the double bonds during frying increases the content of conjugated dienes (LIMA; GONÇALVES, 1994; GERDE et al., 2007). This finding was observed in the present study since the used oils presented relatively greater amounts of conjugated dienes than that of the fresh oil, 0.41 to $0.98 \%$ and $0.15 \%$, respectively. 
Table 5. Induction period (h) of the frying oils at $130^{\circ} \mathrm{C}^{\mathrm{a}}$.

\begin{tabular}{lrrrr}
\hline \multicolumn{1}{c}{ Sample } & Chicken & \multicolumn{1}{c}{ Meat } & \multicolumn{1}{c}{$\begin{array}{c}\text { Inert } \\
\text { material }\end{array}$} & $\begin{array}{c}\text { Heating } \\
\text { only }\end{array}$ \\
\hline Day 0 (Fresh Oil) & $11.8 \pm 0.1$ & $12.3 \pm 0.2$ & $12.3 \pm 0.2$ & $12.3 \pm 0.2$ \\
Last day of use ${ }^{\mathrm{b}}$ & $4.8 \pm 0.1$ & $6.4 \pm 0.0$ & $0.9 \pm 0.1$ & $0.3 \pm 0.1$ \\
\hline
\end{tabular}

${ }^{a} 5 \mathrm{~g}$ of samples and air flow of $9.2 \mathrm{~L} / \mathrm{h}$; ${ }^{\mathrm{b}}$ Explanation of Discard: Day 7 for the frying cycle of the meat and day 17 for the frying cycle of the chicken, inert material and oil subjected only to heating.

The formation of conjugated dienes is also related to the increase in color since the double bounds cause the absorption of larger amounts of blue light causing an increase in orange and brown colors in the oil (LIMA; GONÇALVES, 1994).

When the oil submitted only to heating at $182{ }^{\circ} \mathrm{C}$ was compared with the oil subjected to the action of the water present in the inert material, it could be seen that the latter underwent more pronounced darkening than the former, with red color values of $5.8 \pm 0.2$ units and $2.9 \pm 0.2$ units when read in 0.5 " cuvettes, respectively (the corresponding yellow color values were $27 \pm 6$ units and $17 \pm 3$ units, respectively). However, the red color values of these oils values were smaller than that of the oil used for frying breaded chicken during the same period of 17 days, $9.2 \pm 1.6$ units $(0.5$ " cuvette; $37 \pm 23$ units for yellow). In the case of breaded meat, after 7 days of frying, the red color value of the oil was $3.7 \pm 0.5$ units (and the yellow color value was $29 \pm 12$ units) using the same cuvettes.

At elevated temperatures, the food residues become caramelized turning into carbonized particles in suspension and hence darkening the oil (PAUL; MITTAL, 1997). Dark compounds resulting from the Maillard reaction (BELITZ; GROSCH, 1999) as also polymeric compounds (STEVENSON; VAISEY-GENSER; ESKIN, 1984) can also be formed darkening the oil.

\subsection{Tocopherols and tocotrienols}

The loss of tocopherols during frying may be considered a measure of the level of oil degradation since tocopherols degrade faster in oils heated at frying temperatures than at room temperature (PLEISS; MEREDITH, 1999; WARNER; SU; WHITE, 2004). However, the content of tocopherols and tocotrienols in the fresh oil and in the refined palm olein (BERGER, 2005) was rather low.

In the present study, the fresh palm olein presented $26 \mathrm{mg} .100 \mathrm{~g}^{-1}$ of a-tocopherol, $5.0 \mathrm{mg} .100 \mathrm{~g}^{-1}$ of $\beta$-tocopherol, $2.0 \mathrm{mg} .100 \mathrm{~g}^{-1}$ of $\gamma$-tocopherol, $3.5 \mathrm{mg} .100 \mathrm{~g}^{-1}$ of $\delta$-tocopherol, $29 \mathrm{mg} .100 \mathrm{~g}^{-1}$ of $\alpha$-tocotrienol, $35.5 \mathrm{mg} .100 \mathrm{~g}^{-1}$ of $\gamma$-tocotrienol, and $12.0 \mathrm{mg} .100 \mathrm{~g}^{-1}$ of $\delta$-tocotrienol.

The greatest reduction of these compounds in the oils during heating/frying was observed for the $\gamma$-tocotrienol content, in which it was reduced to non-detectable levels in the oil samples submitted only to heating and in those used for frying the inert material. It was reduced to $3 \mathrm{mg} .100 \mathrm{~g}^{-1}$ and $19 \mathrm{mg} .100 \mathrm{~g}^{-1}$ in the oils used for frying breaded chicken and meat, respectively. The smallest reductions were observed for a-tocopherol, showing values of $16 \mathrm{mg} .100 \mathrm{~g}^{-1}, 31 \mathrm{mg} .100 \mathrm{~g}^{-1}$,
$6.2 \mathrm{mg} .100 \mathrm{~g}^{-1}$, and $21 \mathrm{mg} .100 \mathrm{~g}^{-1}$, respectively, in the oil samples used for frying chicken, meat, and the inert material and also in that submitted only to heating.

\subsection{Fatty acid composition}

The fresh palm olein had the following fatty acid composition: $36.2 \%$ of palmitic acid (16:0), $4.4 \%$ of stearic acid (18:0), $46.3 \%$ of oleic acid (18:1), 10.6\% of linoleic acid (18:2), $0.3 \%$ of linolenic acid (18:3), and $0.2 \%$ of trans isomers, in addition to other minority fatty acids, such as 12:0, 14:0 and 20:0.

The fatty acid composition of the discarded frying oil did not change significantly when compared to that of the fresh oil in any of the cases (oil used for frying breaded chicken, breaded meat, or the inert material and that subjected only to heating at $\left.182^{\circ} \mathrm{C}\right)$.

In general, there was a slight decrease in linoleic acid during the frying cycles due to lipid oxidation and the formation of polar compounds during the frying process, which is in agreement with other reports in the literature (MACHADO; GARCÍA; ABRANTES, 2008). The linoleic acid content of samples after frying decreased from $10.6 \%$ to $8.8 \%$ (frying of breaded chicken); $9.7 \%$ (frying of breaded meat); $8.6 \%$ (frying of inert material), and $7.7 \%$ (only heating). Regarding the saturated fatty acids, which apparently increased due to the quantifying method adopted, it must be considered that the derivatization method related to the methylic ester formation does not take into account the minority compounds formed during frying, such as oxydized polar compounds. This fact makes one believe that there is an increase in the saturated fatty acid content, which is not true. In the samples of discarded oil (last day of use), the maximum trans isomer content was $1.3 \%$, which was found in the sample submitted only to heating at $182^{\circ} \mathrm{C}$. Considering that the recommended daily intake of vegetable oil is 1 tablespoon or $15 \mathrm{~mL}$ (FOOD..., 2009a), the equivalent of approximately $13.5 \mathrm{~g}$, it is estimated that it could contain $0.18 \mathrm{~g}$ trans isomers, which could be listed as "zero" trans-fat on food labels (FOOD..., 2009b).

Therefore, it was shown that the formation of trans isomers during frying at temperatures below $185^{\circ} \mathrm{C}$ was insignificant when considering its recommended daily intake, in agreement with a previous study (SAGUY; DANA, 2003; ALADEDUNYE; PRZYBYLSKI, 2009).

\subsection{Alterations in foods during frying}

The raw breaded chicken presented a moisture content of $64.7 \pm 0.4 \%$ and oil content of $1.6 \pm 0.2 \%$. After frying, the food showed a reduction in moisture content and an increase in oil content. On the first day of frying, the moisture of the fried chicken was $56.1 \pm 0.1 \%$ and the oil content was $12.2 \pm 0.0 \%$. On the $7^{\text {th }}$ day, the moisture content had reduced to $48.6 \pm 0.5 \%$, and the oil content reduced slightly to $10.2 \pm 0.9 \%$.

With respect to the alterations occurring in the foods during frying, it can be observed that for the breaded meat the variation in the moisture content on the $6^{\text {th }}$ day of frying was practically zero $(43.3 \pm 0.2 \%$ and $43.3 \pm 1.5 \%$, respectively), 
and the increase in the absorption rate of the oil was not so expressive ( $10.1 \pm 1.6 \%$ to $14.0 \pm 0.8 \%)$. This may be due to the fact that the oil used to fry the breaded meat did not undergo polymerization (Table 3 ) and an insignificant increase in the rate of oil absorption is expected for a fixed frying time. As the oil degrades more surfactants are formed and there is an increase in the time of contact between the food and the oil. As a result, the amount of oil absorbed by the food and the rate of heat transfer increases producing excessive drying and darkening of the surface depending on the temperature gradient (PAUL; MITTAL, 1997).

On the other hand, on the last day of frying before discarding the oil, the breaded chicken fried in the palm olein presented a considerable reduction in moisture content when compared with the breaded chicken fried on the first day of frying with the fresh oil, from $56.1 \pm 0.1 \%$ to $48.6 \pm 0.5 \%$. The oil content of the fried chicken decreased from $12.2 \pm 0.0 \%$ on the first day of frying to $10.2 \pm 0.9 \%$ on the $7^{\text {th }}$ day of frying. The previously mentioned theory of the formation of surfactants (PAUL; MITTAL, 1997) explains the greater absorption of the oil and the reduced moisture content of the food fried in the polymerized oil.

\section{Conclusions}

Comparing the longer use of the palm olein for frying the breaded chicken with that of the oil used for frying the breaded meat $(17 \times 7$ days), the compositions of the foods, and the changes in the oil samples used to fry the meats and those in the oil sample submitted only to heating and hydrolytic degradation, it was concluded that the higher content of water in the chicken and the smaller amount of flour (or bread crumbs) from the breaded chicken floating in the oil were responsible for this difference. The water exerted a protective effect against thermal degradation of the oil used in the deep-fat frying of breaded chicken, which allowed it to be used longer than the oil used in frying breaded meat.

\section{Acknowledgements}

The authors are grateful to Agropalma for donating the palm olein, to Braslo for the food samples, to McDonald's for the fryer, to Mr. Antonio Castellón for technical support about the use of the Viscofrit test, to Mr. José Carlos Cazzoli (frais@ sigmanet.com.br) of Frais Imp. and Exp. Ltda. for the loan of the Fri-Check ${ }^{\circledR}$, to Testo do Brasil for monitoring the analyses performed with Testo 265, and to $\mathrm{CNPq}$ for the doctorate research grant (Process: 140387/2005-6).

\section{References}

ALADEDUNYE, F. A.; PRZYBYLSKI, R. Degradation and nutritional quality changes of oil during frying. Journal of the American Oil Chemists' Society, v. 86, p. 149-156, 2009.

AMERICAN OIL CHEMISTS' SOCIETY - AOCS. Official methods and recommended practices of the American Oil Chemists' Society. Champaign: AOCS, 2004.

BASIRON, Y. Palm oil. In: SHAHIDI, F. (Ed.). Bailey's industrial oil and fat products. New Jersey: John Wiley, 2005. v. 2, cap. 8.
BELITZ, H. D.; GROSCH, W. Food chemistry. 2nd. ed. Berlim: Springer, 1999. cap. 3.

BERGER, K. G. The use of palm oil in frying. Selangor: Malaysian Palm Oil Promotion Council, 2005. 113 p.

CALLIAUW, G. H.; GIBON, V.; GREYT, W. F. J. D. Principles of palm olein fractionation: a bit of science behind the technology. Lipid Technology, v. 19, n. 7, p. 152-155, 2007. http://dx.doi.org/10.1002/ lite. 200700050

DANA, D.; BLUMENTHAL, M. M.; SAGUY, I. S. The protective role of water injection on oil quality in deep fat frying conditions. European Food Research and Technology, v. 217, p. 104-109, 2003. http://dx.doi.org/10.1007/s00217-003-0744-x

DOBARGANES, M. C.; VELASCO, J.; DIEFFENBACHER, A. Determination of polar compounds, polymerized and oxidized triacylglycerols, and diacylglycerols in oils and fats. Pure and Applied Chemistry, v. 72, n. 8, p. 1563-1575, 2000. http://dx.doi. org/10.1351/pac200072081563

GEE, P. T. Analytical characteristics of crude and refined palm oil and fractions. European Journal of Lipid Science and Technology, v. 109, p. 373-379, 2007. http://dx.doi.org/10.1002/ejlt.200600264

GERDE, J. et al. Frying performance of no-trans, low-linolenic acid soybean oils. Journal of the American Oil Chemists' Society, v. 84, n. 6, p. 557-563, 2007.

FOOD AND DRUG ADMINISTRATION - FDA. Food Labeling Guidance \& Regulatory Information: 101.12 Reference amounts customarily consumed per eating occasion. FDA, 2009a. Disponível em: <http://www.fda.gov>. Acesso em: 12 set. 2009.

FOOD AND DRUG ADMINISTRATION - FDA. Food Labeling Guidance \& Regulatory Information: 101.9 Nutrition labeling of food. FDA, 2009b. Disponível em: <http://www.fda.gov>. Acesso em: 12 set. 2009.

HARTMAN, L.; LAGO, R. C. A. Rapid preparation of fatty acid methyl esters from lipids. Laboratory Practices, v. 22, p. 475-476, 1973. PMid:4727126.

HORWITZ, W. Official Methods of Analysis of Association of Official Analytical Chemists. 13th. ed. Washington: AOAC, 1980.

KALOGIANNI, E. P.; KARASTOGIANNIDOU, C.; KARAPANTSIOS, T. D. Effect of the presence and absence of potatoes under repeated frying conditions on the composition of palm oil. Journal of the American Oil Chemists' Society, v. 86, p. 561-571, 2009.

LAI, O.-M. Palm oil, its fractions, and components. In: AKOH, C. C.; LAI, O.-M. (Eds.). Healthful lipids. Illinois: AOCS, 2005. cap. 30.

LAWSON, H. Aceites y grasas alimentarios: tecnología, utilización y nutrición. Zaragoza: Acribia, 1994. cap. 7.

LIMA, J. R.; GONÇALVES, L. A. G. Parâmetros de avaliação da qualidade de óleo de soja utilizado para fritura. Química Nova, v. 17, n. 5 , p. 392-396, 1994.

MACHADO, E. R.; GARCÍA, M. C. D.; ABRANTES, S. Alterações dos óleos de palma e de soja em fritura descontínua de batatas. Ciência e Tecnologia de Alimentos, v. 28, n. 4, p. 786-792, 2008. http:// dx.doi.org/10.1590/S0101-20612008000400004

MAN, Y. B. C. et al. Quality changes of refined-bleached-deodorized (RBD) palm olein, soybean oil and their blends during deep-fat frying. Journal of Food Lipids, v. 6, p. 181-193, 1999. http://dx.doi. org/10.1111/j.1745-4522.1999.tb00142.x

MARMESAT, S. et al. Quality of used frying fats and oils: comparison based on chemical and physical oil properties. International Journal of Food Science and Technology, v. 42, p. 42, 601-608, 2007. 
OSAWA, C. C. Testes rápidos (kits) para avaliação da qualidade de óleos, gorduras e produtos que os contenham e sua correlação com os métodos oficiais da AOCS. 2005. 403 f. Dissertação (Mestrado em Tecnologia de Alimentos)-Faculdade de Engenharia de Alimentos, Universidade Estadual de Campinas, Campinas, 2005.

OSAWA, C. C.; GONÇALVES, L. A. G.; RAGAZZI, S. Titulação potenciométrica aplicada na determinação de ácidos graxos livres de óleos e gorduras comestíveis. Química Nova, v. 29, n. 3, p. 593-599, 2006. http://dx.doi.org/10.1590/S010040422006000300031

PAUL, S. P.; MITTAL, G. S. Regulating the use of degraded oil/fat in deep-fat/oil food frying. Critical Reviews in Food Science and Nutrition, v. 37, n. 7, p. 635-662, 1997. PMid:9408730. http://dx.doi. org/10.1080/10408399709527793

PLEISS, L. M.; MEREDITH, A. J. Palm olein quality parameter changes during industrial production of potato chips. Journal of the Americal Oil Chemists' Society, v. 76, n. 6, p. 731-738, 1999.
SAGUY, I. S.; DANA, D. Integrated approach to deep fat frying: engineering, nutrition, health and consumer aspects. Journal of Food Engineering, v. 56, p. 143-152, 2003. http://dx.doi. org/10.1016/S0260-8774(02)00243-1

SHAHIDI, F.; WANASUNDARA, J. P. D.; Extraction and analysis of lipids. In: AKOH, C. C.; MIN, D. B. (Eds.). Food lipids: chemistry, nutrition, and biotechnology. New York: Marcel Dekker, 1998. cap. 5.

STEVENSON, S. G.; VAISEY-GENSER, M.; ESKIN, N. A. M. Quality control in the use of deep frying oils. Journal of the Americal Oil Chemists' Society, v. 61, n. 6, p. 1102-1108, 1984.

WARNER, K. Chemical and physical reactions in oil during frying. In: GUPTA, M. K.; WARNER, K.; WHITE, P. J. (Orgs.). Frying technology and practices. Champaign: AOCS Press, 2004. cap. 2, p. $16-28$.

WARNER, K.; SU, C.; WHITE, P. J. Role of antioxidants and polymerization inhibitors in protecting frying oils. In: GUPTA, M. K.; WARNER, K.; WHITE, P. J. (Orgs.). Frying: technology and practices. Champaign: AOCS Press, 2004. cap. 4, p. 37-49. 